\title{
Perbandingan Pengisian Jabatan Hakim antara Indonesia dengan Jepang
}

\author{
Haris Kurnia Anjasmana \\ Universitas Padjadjaran \\ hariskurnia03@gmail.com
}

DOI: $10.23917 /$ jjr.v9i2.8726

Submission
Track:
Received:
28 Agustus 2019
Final Revision:
13 Desember 2019
Available online:
17 Januari 2020
Corresponding
Author: Fadzlurrahman
Universitas Padjadjaran
hariskurnia03@gmail.com

ABSTRAK

Tujuan: Artikel ini bertujuan untuk mengetahui dan menganalisis bagaimana perbedaan pengisian jabatan hakim tingkat pertama antara Indonesia dengan Jepang.

Metodologi:Metode Penelitian Yuridis Normatif yang dilakukan melalui penelitian kepustakaan, data yang dicari adalah data sekunder dengan menggunakan bahan hukum primer, sekunder, tersier. Dalam kaitannya dengan penlitian ini maka menggunakan semua publikasi hukum yang terkait dengan objek penelitian yang terdiri dari, bukubuku teks, jurnal hukum, Selain itu juga akan digunakan bahan-bahan non hukum sepanjang relevan dan mendukung hasil penelitian.

Temuan: Mekanisme pengisian jabatan hakim di jepang kembali lebih baik sebab prosesnya dilakukan secara terbuka, selektif, dan kompetitif, banyak tahapan yang harus dilalui calon hakim itu bisa diangkat menjadi hakim baik persyaratan, strata pendidikan, pengalaman dibidang hukum, metode ujian. Ditambah Jepang telah memiliki model kompetensi standar yang dijadikan acuan dalam proses rekrutmen maupun pelatihan bagi calon hakim selain itu, dalam model acuan itu terdapat karakter ideal yang sepatutnya dipunyai oleh setiap hakim sehingga lahir hakim yang mempunyai kualitas dan mutu yang sama bagusnya. Indonesia sendiri menurut penulis dari segi mekanisme pengisian hakim belum sepenuhnya mampu secara maksimal menghasilkan hakim yang berkualitas dan berintegritas.

Kegunaan: Penelitian ini bermanfaat terutama bagi Indonesia untuk setidaknya belajar dan mengambil mekanisme rekrutmen hakim di jepang yang dirasa lebih baik dan telah mempunyai metode dan pola yang mapan.

Kebaruan/Orisinalitas: orisinalitas terkait dengan masih belum 
banyaknya yang membahas terkait dengan sistem rekrutmen calon hakim yang diatur dalam Peraturan Mahkamah Agung Nomor 2 Tahun 2017 dimana pengisian jabatan hakim melalui seleksi ala CPNS ditambah dengan proses pelaksanaan rekrutmen hakim itu dibandingkan dengan mekanismen seleksi hakim di Jepang.

Keywords:Pengisian, rekrutmen, hakim, Indonesia, Jepang

\section{PENDAHULUAN}

Kekuasaan kehakiman itu merupakan prasyarat penting dalam suatu negara hukum(Rimdan, 2012). Ciri khas dari negara hukum itu adalah peradilan yang bebas dan tidak memihak serta tidak dipengaruhi oleh suatu kekuasaan atau kekuatan apapun. Peraturan perundang-undangan yang ada berkenaan dengan hakim baik Undang-Undang Kekuasaan Kehakiman dan Semua Badan Peradilan pada dasarnya Hakim telah jelas kedudukannya sebagai Pejabat Negara.Undang-Undang Nomor 48 Tahun 2009 tentang Kekuasaan Kehakiman mengatur bahwa Hakim itu sebagai Pejabat Negara, ketentuan Calon Hakim terlebih dahulu harus menjadi Pegawai Negeri Sipil dihilangkan, tetapi permasalahan kembali muncul karena dalam Undang-Undang Nomor 48 Tahun 2009 tentang Kekuasaan Kehakiman tidak ada satupun pasal yang mengatur mengenai tata cara ataupun mekanisme dalam pengadaan dan rekrutmen hakim sehingga dari sejak Undang-Undang Kekuasaan Kehakiman tahun 2009 sampai tahun 2017 ini tidak pernah lagi dilakukan rekrutmen calon Hakim terutama di lingkungan Mahkamah Agung.

Keinginan Mahkamah Agung untuk melakukan rekrutmen hakim secara mandiri (appointment by judiciary itself) ada benarnya demi mewujudkan kekuasaan kehakiman yang independen dan imparsial (Alia, 2017). Apalagi keinginan itu juga diakomodasi oleh Mahkamah Konstitusi (MK) melalui putusannya Nomor 43/PUU-XIII/2015 tentang pengujian terhadap Undang-Undang Nomor 49 Tahun 2009 tentang Peradilan Umum, Undang-Undang Nomor 50 Tahun 2009 tentang Pengadilan Agama, dan Undang-Undang Nomor 51 Tahun 2009 tentang Pengadilan Tata Usaha Negara. Mahkamah Konstitusi menegaskan bahwa proses rekrutmen hakim (judicial selection and appointment) merupakan kompetensi absolut dari Mahkamah Agung. Ketentuan yang mengharuskan rekrutmen hakim dilakukan bersama dengan Komisi Yudisial dianggap inkonstitusional oleh MK, sebab dapat mengancam independensi Mahkamah Agung. Sehingga dampaknya dapat dilihat bahwa Komisi Yudisial 
tidak berwenang lagi ikut terlibat dalam proses rekrutmen hakim bahkan KY tidak bisa mengawasi jalannya rekrutmen tersebut (pengujian terhadap Undang-Undang Nomor 49 Tahun 2009 tentang Peradilan Umum, Undang-Undang Nomor 50 Tahun 2009 tentang Pengadilan Agama, dan Undang-Undang Nomor 51 Tahun 2009 tentang Pengadilan Tata Usaha Negara, 2015).

Perdebatan pun mulai muncul bagaimana mekanisme rekrutmen Hakim apakah akan menggunakan sistem rekrutmen seperti pejabat negara lain, atau menggunakan cara yang lain sesuai dengan kedudukan hakim sebagai pejabat negara.Pada prakteknya pejabat negara yang lazim di Indonesia dibatasi masa jabatannya, memiliki kualifikasi khusus, proses rekrutmen yang ketat melalui panitia seleksi yang terdiri dari berbagai lembaga terkait dan mekanisme akuntabilitas kinerja yang transparan kepada publik. Sebagai konsekuensi status Hakim menjadi Pejabat Negara permasalahan pun makin kompleks karena Mahkamah Agung sebagai lembaga yang berwenang dalam hal pengadaan dan rekrutmen hakim malah kembali menggunakan sistem rekrutmen ala Pegawai Negeri Sipil dalam proses rekrutmen calon hakim, hal itu dapat dilihat dengan dikeluarkannya Peraturan Mahkamah Agung (PERMA) Nomor 2 Tahun 2017 tentang Pengadaan Hakim.

Berkaitan dengan hal tersebut diatas, maka disini penulis berkeinginan untukmengkaji, meneliti dan membandingkan proses rekrutmen hakim yang ada di Indonesiadengan yang ada di Jepang. Adapun alasan dari penulis memilih jepang karena kekuasaan yudikatif di jepang ada kesamaan dengan kekuasaan yudikatif di Indonesia, dimana kekuasaan yudikatif jepang terletak di tangan Mahkamah Agung dan ada pengadilan-pengadilan yang lebih rendah, seperti pengadilan tinggi, pengadilan distrik, dan pengadilan sumir. manajemen hakim di jepang itu menggunakan sistem karier, lalu ada ujian negara yang dilakukan untuk melakukan seleksi hakim, hampir sama dengan sistem rekrutmen hakim di Indonesia. Ditambah mekanisme rekrutmen hakim di jepang dianggap salah satu yang terbaik di asia karena seleksi melalui beberapa tahap penyaringan yang sangat ketat yang memungkinkan dapat dijadikan contoh bagi Indonesia untuk dapat dijadikan referensi penting bagi perbaikan sistem utamanya berkaitan dengan rekrutmen hakim di Indonesia sehingga dapat melahirkan hakim yang berkualitas dan berintegritas.

Permasalahan yang akan dibahas dalam tulisan ini adalah sejauh mana perbandingan mekanisme pengisian jabatan hakim di Indonesia dan Jepang mampu untuk menghasilkan hakim yang berkualitas dan berintegritas? 


\section{METODE PENELITIAN}

Metode Penelitian Yuridis Normatif yang dilakukan melalui penelitian kepustakaan, data yang dicari adalah data sekunder dengan menggunakan bahan hukum primer, sekunder, tersier. Dalam kaitannya dengan penlitian ini maka menggunakan semua publikasi hukum yang terkait dengan objek penelitian yang terdiri dari, bukubuku teks, jurnal hukum, Selain itu juga akan digunakan bahan- bahan non hukum sepanjang relevan dan mendukung hasil penelitian.

\section{HASIL DAN PEMBAHASAN}

Mekanisme mengenai pengisian jabatan hakim itu menimbulkan pertanyaan selanjutnya apakah mekanisme pengisian jabatan hakim itu telah mampu atau tidak untuk menghasilkan hakim yang berkualitas yang tercermin dari putusan yang dihasilkan maupun etika si hakim sendiri.Rekrutmen hakim sebagai orang yang memutuskan suatu perkara sesuai dengan prinsip keadilan berdasarkan Ketuhanan Yang Maha Esa harus dilakukan secara profesional, transparan melalui proses seleksi yang harusnya sangat ketat. Kriteria seorang hakim integritas harusnya lebih penting dibandingkan cuma sekedar kemampuan akademik, dimana integritas hakim lah yang sangat menentukan baik atau tidaknya suatu putusan. Track record yang jelas dan terukur harus dilakukan untuk menghasilkan hakim yang berkualitas dan berintegritas. Penulis akan menguraikan sejauh mana sejauh mana mekanisme pengisian jabatan hakim di indonesia dan jepang mampu untuk menghasilkan hakim yang berkualitas dan berintegritas dalam beberapa sub-pokok pembahasan.

\section{Mekanisme pengisian jabatan hakim}

- Indonesia

Adapun mekanisme pengisian seleksi calon hakim di pengadilan tingkat pertama dijelaskan pada Pasal 3 Peraturan Mahkamah Agung (PERMA) Nomor 2 Tahun 2017 menyatakan:

"Pengadaan Hakim dilakukan dengan beberapa tahapan yaitu:
a. perencanaan,
b. Pengumuman
c. pendaftaran,
d. pelamaran,
e. pelaksanaan seleksi,
f. pengumuman hasil seleksi,
g. pengangkatan CPNS/Cakim, 
h. pengangkatan PNS/Cakim,

i. pengangkatan hakim

Pasal 5 menyatakan:"pelaksanaan seleksi pengadaan hakim terdiri atas:

a. seleksi administrasi,

b. seleksi kompetensi dasar,

Adapun Nilai Ambang Batas Seleksi Kompetensi Dasar adalah nilai minimal yang harus dipenuhi oleh setiap peserta ujian seleksi Calon Pegawai Negeri Sipil. Pada Pasal 2 PermenPANRB Nomor 22 Tahun 2017 tersebut disebutkan bahwasannya seleksi kompetensi dasar Calon Pegawai Negeri Sipil Tahun 2017 meliputi 3 macam jenis tes, yaitu:

i. tes karateristik pribadi;

ii. tes intelegensia umum; dan

iii. tes wawasan kebangsaan.

c. seleksi kompetensi bidang,

d. seleksi substansi hukum,

e. psikotes,

f. wawancara,

g. baca kitab (khusus untuk calon hakim Pengadilan Agama)

Adapun Tahapan seleksi penerimaan Calon Hakim Mahkamah Agung RI Tahun Anggaran 2017 yang diumumkan melalui Pengumuman Mahkamah Agung Nomor: 01/Pansel/MA/07/2017 dilakukan dengan tahapan yaitu:

a) Seleksi adminsitrasi

b) Seleksi kompetensi dasar (SKD) dengan Computer Assisted Test (CAT)

1) peserta yang lulus seleksi administrasi berhak mengikuti SKD sesuai dengan lokasi tes yang dipilih

2) peserta yang lulus SKD sebanyak 3 (tiga) kali jumlah formasi berikutnya berhak mengikuti SKD

3) standar kelulusan SKD dan SKB diatur dengan peraturan menteri PAN dan RB

c) Seleksi Kompetensi Bidang terdiri dari:

1) Tes materi bidang hukum menggunakan Computer Assisted Test(CAT) dengan bobot $50 \%$;

2) Psikotes dengan bobot $25 \%$;

3) Wawancara dengan bobot $25 \%$;

4) Khusus pelamar calon hakim pengadilan agama ditambah memahami dan membaca kitab kuning;

d) Integrasi nilai SKD dan SKB berdasarkan PermenPANRB Nomor 20 Tahun 2017

e) Pengumuman hasil seleksi akhir

1) Hasil seleksi akhir merupakan nilai kumulatif dari SKD dan SKB

2) Peserta dengan rangking tertinggi sesuai dengan jumlah formasi dinyatakan lulus seleksi Calon Hakim dengan surat keputusan kepala seleksi, hasil putusan tidak dapat diganggu gugat. 
Bentuk soal yang dipergunakan dalam ujian tertulis adalah pilihan ganda (multiple choice). Dalam tahap wawancara dan psikotes, dimana pada seleksi Calon Hakim tahun 2017 peserta diwawancarai oleh penginterview dari internal mahkamah agung yang kebanyakan hakim serta akademisi dari universitas terkemuka. Selain test kepribdian, setiap peserta seleksi akan diwawancarai mengenai hal-hal seputar motivasi, pengetahuan umum dan pengetahuan hukum.

Calon Hakim yang telah lolos seleksi yang kemudian diwajibkan mengikuti pendidikan Calon Hakim. Adapun tahapan proses Pendidikan hakim yaitu 1) pradiklat dimana calon hakim berstatus Pegawai Negeri Sipil (PNS) dan dalam tahap menunggu untuk mengikuti diklat; 2) Diklat dimana Calon Hakim mengikuti pendidikan di Pusat Pendidikan dan Latihan (Pusdiklat) MA; 3) Pascadiklat dimana cakim ditempatkan di pengadilan tingkat pertama untuk jangka waktu yang tidak ditetapkan, tetapi minimal kurang lebih dua tahun sebelum pengangkatan sebagai hakim. Pada proses ini cakim akan dididik sebagai asisten panitera pengganti dan asisten hakim, proses akhirnya apabila dinyatakan lulus pendidikan Calon Hakim, maka proses berikutnya akan diangkat sebagai Hakim.dan terhadap Calon Hakim yang dinyatakan tidak lulus Pendidikan Hakim, dimana berdasar pada Peraturan Mahkamah Agung (PERMA) Nomor 2 tahun 2017 tentang Pengadaan Hakim akan diberhentikan sebagai PNS.

- Jepang

Adapun alur untuk bisa menjadi hakim di jepang yaitu: (Yudisial, 2015)

1) Setelah lulus dari Fakultas Hukum dan melanjutkan ke Law School selama 2-3 tahun (law School setara dengan strata 2/ magister hukum).

2) Lulus ujian hukum negara agar bisa masuk ke Legal Training and Research Institute (satu-satunya lembaga yang merekrut dan melatih calon aparat penegak hukum di Jepang).

3) Mengikuti pendidikan di Legal Training and Research Institute selama 12 bulan untuk mengikuti pelatihan khusus calon penegak hukum yang dilaksanakan oleh Second Division of LTRI .

4) Calon hakim yang lulus ujian akan diusulkan dan diangkat menjadi asisten hakim selama 10 tahun, setelah itu baru kemudian mereka diangkat menjadi hakim. 
Proses seleksi sekaligus Pembinaan calon hakim di Jepang dimulai dengan menempuh Pendidikan hukum yang berjenjang di perguruan tinggi, yang disebut dengan Law School dan setara dengan Strata 2 (magister). Law School menerima peserta program atau mahasiswa baik dari lulusan Fakultas Hukum maupun non Fakultas Hukum. Untuk rekrutmen Law school, setiap peserta harus mengikuti seleksi ketat antara lain tes bakat kemampuan dasar dan materi hukum terutama hukum acara . Para pengajar berasal dari lingkungan akademisi, profesional hukum (hakim, jaksa dan advokat). Bahkan lulusan 10 besar lulusan terbaik Fakultas Hukum di Universitas terkemuka Jepang akan diberikan keistimewaan untuk bisa langsung direkrut menjadi calon hakim tanpa harus mengikuti ujian negara. (Syahuri, 2013)

Ujian seleksi calon hakim ini rata-rata diikuti 7 ribu hingga 8 ribu orang. Calon Hakim yang diluluskan sekitar 1600 orang. Materi pelatihan untuk tiap-tiap profesi penegak hukum juga tidak dibedakan, 1600 orang yang mengikuti pelatihan hingga tuntas itu harus melakoni ujian tahap dua. Tahap ini, tiap-tiap peserta diberi kesempatan untuk memilih profesi yang akan digelutinya. Materi ujian disesuaikan dengan pilihan profesi mereka (Badilag Mahkamah Agung, 2017).

Calon penegak hukum (hakim, jaksa, pengacara) di Jepang harus menjalani pelatihan selama 12 bulan. Setiap peserta Law Schooldiharuskan mengikuti ujian akhir. Apabila lulus, para calon penegak hukum tersebut mengikuti ujian nasional yang diselenggarakan oleh pemerintah, yaitu Departemen Kehakiman Jepang. Setelah dinyatakan lulus ujian nasional, para peserta mengikuti Pendidikan dan Latihan Profesi Hukum selama 1 (satu) tahun dengan perincian: 10 bulan pelatihan lapangan (magang) dan 2 bulan pelatihan kolektif di LTRI. Lalu setelah masa pelatihan selesai dilakukan ujian akhir. Kemudian setelah melalui evaluasi yang ketat, maka mereka berdasarkan kompetensi dan bakatnya disalurkan atau diarahkan menjadi hakim, jaksa dan advokat.

Empat tahapan pelatihan di LTRI berupa: (Yudisial, 2015)

i. Introductory Training Courses, yaitu pelatihan pengantar bagi para hakim, asisten hakim, dan hakim pengadilan summary court pada penunjukkan atau tugas baru atau jabatan mereka

ii. Fields-Specific Workshops. Workshop ini agar hakim menemukan bidang khusus dan meningkatkan kemampuan hakim.

iii. Comprehensive Workshops. Pelatihan untuk mempelajari berbagai masalah di lapangan.

iv. Dispatch-style Training Courses. Hakim mengunjungi perusahaan swasta dan badan lain di luar pengadilan untuk jangka waktu tertentu dengan mengamati dan mengalami praktik bisnis di sana. Tujuan dari pelatihan ini adalah untuk memberikan 
kesempatan kepada para hakim untuk meningkatkan pemahaman mereka tentang kondisi aktual ekonomi, memperluas perspektif, dan memperdalam wawasan mereka.

Peserta yang lulus ujian selanjutnya mengikuti pelatihan pada Legal Training and Research Institute di bawah bimbingan Ketua Mahkamah Agung dan Sekretaris Jenderal lembaga tersebut selama 2 tahun yang per 4 bulan melakukan tour of duty di 4 tempat. Pertama ditempatkan di kantor pengacara, setelah itu di kantor kejaksaan selanjutnya di pengadilan pidana dan pengadilan perdata masing-masing selama 4 bulan. Sebelum lulus dari pelatihan tersebut, para peserta boleh mengajukan lamaran untuk jabatan hakim (Marzuki, 2018).

Pelatihan lapangan dilakukan di 50 lokasi di seluruh negeri yaitu di Pengadilan, Kantor Penuntut Umum (Kejaksaan) dan Asosiasi Pengacara. Tujuan dari pelatihan ini adalah untuk membiasakan peserta pelatihan dengan kondisi aktual dari urusan praktek hukum dan bagaimana menguasai persoalan dengan cara yang tepat, sikap mental, etika dan lain-lain dari seorang ahli atau penegak hukum professional. Calon hakimdiminta benar-benar menguasai dan mengetahui cara menyelesaikan suatu persoalan sesuai instruksi (Council, 1999).

Kurikulum nasional dan silabus Law Schooldiatur oleh UU di Jepang. Setiap perguruan tinggi di Jepang membuka Law School, sehingga dalam setiap tahunnya menghasilkan lulusan yang cenderung meningkat. Masa studi Law School selama 2-3 tahun. Law Schoolbertujuan untuk mendidik para calon profesi hukum antara laincalon profesi jaksa, calon profesi advokat dan calon profesi hakim. Ketiga profesi tersebut mendapatkan pendidikan dan materi yang sama tentang hukum. praktisi hukum/professional hukum memiliki visi, misi, serta persepsi yang sama tentang penerapan dan penegakan hukum di Jepang (Parlina, 2018). Lulus dari Law School, mereka akan melanjutkan pendidikan ke Legal Training dan Research Institute (LTRI) selama 1 tahun, kemudian kabinet akan menunjuk lulusan LTRI untuk mengisi posisi sebagai asisten hakim terlebih dahulu. Asisten hakim yang ditunjuk adalah orang-orang yang sudah lulus ujian hukum negara dan telah lulus dari pelatihan di LTRI.

Rekrutmen hakim di semua tingkatan peradilan dilakukan oleh dan atas rekomendasi Chief of Justice (Ketua MA) dan Sekretaris Jenderal LTRI. Saat menjabat menjadi asisten hakim, kewenangan mereka tentunya terbatas. Mereka diperbolehkan mengikuti persidangan, tetapi tidak boleh menjadi satu-satunya hakim yang mendengarkan kasus di persidangan. Mereka diperkenankan duduk sebagai anggota dari 3 panel hakim, dan tentunya membantu 
hakim ketua. Mahkamah Agung Jepang juga berwenang untuk menjadikan asisten hakim dengan pengalaman di atas 5 tahun untuk duduk menjadi hakim tunggal.

Calon Hakim dapat menjadi anggota pada majelis hakim di distric court atau memimpin sidang dalam family court atau summary court yang menggunakan hakim tunggal (junus judex)setelah 5 tahun magang sebagai asisten hakim. Mereka akan diangkat kembali sebagai hakim penuh pada pengadilan distrik setelah melaksanakan 10 tahun magang. Promosi asisten hakim untuk naik status menjadi hakim dan pengangkatan kembali hakim, catatan komisi, akan dirujuk secara kolektif apakah hakim itu bisa terpilih lagi atau tidak. Berdasarkan pada laporan yang disiapkan oleh kepala pengadilan di mana para kandidat hakim telah ditempatkan, kandidat yang dianggap sesuai dan layak dengan standar seleksi kemudian diberi bobot penilaian khusus pada pertimbangan akhir mengenai kandidat hakim tersebut. kumpulan informasi yang tersedia sehubungan dengan kandidat dilakuakan tinjauan mencakup informasi yang dikumpulkan oleh komite regional dari pengacara dan jaksa di distrik tempat para kandidat telah ditempatkan .

Hakim yang ditunjuk berasal dari berbagai golongan, yaitu asisten hakim, jaksa penuntut umum, pengacara dan profesor hukum dengan pengalaman minimal 10 tahun di bidangnya masing-masing. Masa kerja hakim di Jepang adalah 10 tahun dan dapat ditunjuk lagi. Hakim senior harus mempunyai masa kerja sebagai hakim selama 20 tahun. Hakim di Jepang akan pensiun di umur 65 tahun. Khusus untuk Summary Courts atau Pengadilan Sumir terdapat aturan khusus, yang bisa ditunjuk sebagai hakim adalah orang yang sudah pernah menjadi hakim atau pernah menjadi ketua pengadilan tinggi, jaksa penuntut umum, pengacara, orang yang memiliki kemampuan atau sudah berpengalaman di praktik pengadilan atau mempunyai pengalaman akademis yang dibutuhkan melalui proses seleksi oleh The Selection Committee for Summary Court Judges. Masa kerja hakim Pengadilan Sumir adalah 10 tahun dan mereka dapat diangkat kembali serta pensiun di umur 70 tahun (Parlina, 2018).

\section{Persyaratan pendaftaran untuk menjadi Hakim}

a. Usia

- Indonesia

Adapun syarat usia untuk bisa menjadi hakim yaitu minimal 22 (dua puluh dua) tahun dan maksimal 32 (tiga puluh dua) tahun. Namunsyarat ini juga menimbulkan kritikan karena dengan syarat minimum berusia 22 tahun untuk mendaftar sebagai hakim dipandang terlalu muda untuk menjadi seorang hakim yang sangat dihormati. Demikian pula 
masa kerjanya sudah seharusnya tidak dikaitkan dengan usia pegawai negeri, karena hakim bukanlah pegawai. Dengan syarat usia itu, bisa saja ada penilaian bahwa para Hakim Pengadilan Tingkat pertama sama saja dan tidak ada bedanya dengan para birokrat muda di berbagai instansi pemerintah yang syarat minimum usianya sama. Padahal Hakim menurut ketentuan Undang Undang adalah Pejabat Negara yang statusnya tidak jauh berbeda dengan Hakim Agung dan Hakim Konstitusi. Bahkan hakim dinilai semakin tua dapat dipandang semakin matang, arif, dan bijaksana.

\section{- Jepang}

Usia minimum untuk hakim biasanya adalah 35 (tiga puluh lima) tahun keatas baru bisa orang itu mendaftar seleksi hakim.Kenapa baru di usia 35 tahun? Karena calon hakim butuh waktu yang Panjang untuk bisa mendaftar sebagai hakim, anggap saja ketika seseorang itu lulus sarjana hukum diusia 22 tahun lalu mereka harus melanjutkan Pendidikan Law School (setingkat magister hukum), selama 2-3 tahun, setelah lulus Law School dan ujian calon hakim, mereka harus mengikuti proses trainee (magang) sebagai asisten hakim selama 10 tahun, setelah itu barulah calon hakim itu bisa mendaftarkan diri untuk menjadi hakim.

\section{b. Strata Pendidikan}

- Indonesia

Tingkat Pendidikan calon hakim itu minimal adalah Sarjana Hukum, bahkan mahasiswa yang baru lulus (fresh graduated) yang belum mempunyai pengalaman di bidang profesi hukum pun bisa ikut dalam seleksi calon hakim. Pertanyaannya sekarang adalah, apakah mungkin posisi Hakim yang sedemikian sentral dan terhormat itu diserahkan pada mereka yang belum perpengalaman dalam proses penegakan hukum ? Kemudian apakah mungkin dalam waktu pendidikan hakim yang hanya 2 (dua) tahun saja bisa mematangkan mereka baik kemampuan teori dan praktek hukum maupun moral mereka sehingga bisa benarbenar siap menjalankan tugas yang berat untuk menghasilkan putusan yang adil dan berkualitas?

Jimly Asshidiqie menegaskan bahwa seharusnya calon yang akan diseleksi dalam seleksi calon hakim diambil dari kelompok profesional, bukan fresh graduated dan dilakukan dengan proses CPNS. Hakim merupakan jabatan khusus, pejabat negara. Atas dasar itu, profesi ini punya kehormatan, bukan jabatan kepegawaian, melainkan jabatan yang harus mempunyai integritas dan kehormatan tertentu untuk direkrut menjadi hakim (Asshidiqie, 2011). 
- Jepang

Lulus dari program sarjana dan melanjutkan ke Law School selama 2-3 tahun (Law School setara dengan magister hukum). Jepang menganggap lulusan Law Schoolitu telah mempunyai kemampuan untuk menguasai ilmu hukum baik teori maupun praktek, cara dan solusi menyelesaikan suatu permasalahan dan mereka telah dididik secara moral dan mental yang kuat sebagai calon hakim.

\section{Lembaga Yang Berwenang Melakukan Seleksi Hakim}

\section{- Indonesia}

Lembaga mana yang diberi kewenangan seleksi pengangkatan hakim tidak secara tegas disebutkan dalam UUD 1945. Lembaga yang berwenang untuk melaksanakan seleksi hakim tingkat pertama baru disebutkan dalam tingkat Undang-Undang yaitu:

a. Undang-Undang Nomor 49 Tahun 2009 tentang Perubahan Kedua Atas UndangUndang Nomor 2 Tahun 1986 tentang Peradilan Umum, pada Pasal 14A ayat (2) dan (3) yang berbunyi:

(2) proses seleksi pengangkatan hakim pengadilan negeri dilakukan bersama oleh mahkamah agung dan komisi yudisial

(3) ketentuan lebih lanjut mengenai proses seleksi diatur bersama oleh mahkamah agung dan komisi yudisial.

b. Undang-undang Nomor 50 Tahun 2009 tentang Perubahan Kedua Atas UndangUndang nomor 7 Tahun 1989 tentang Peradilan Agama, Pasal 13A ayat (2) dan ayat (3) yang berbunyi:

(2) Proses seleksi pengangkatan hakim pengadilan agama dilakukan bersama oleh Mahkamah Agung dan Komisi Yudisial.

(3) ketentuan lebih lanjut mengenai proses seleksi diatur bersama oleh mahkamah agung dan komisi yudisial.

c. Undang-Undang Nomor 51 Tahun 2009 tentang Perubahan Kedua Atas UndangUndang Nomor 5 Tahun 1986 tentang Peradilan Tata Usaha Negara, Pasal 14A ayat (2) dan ayat (3) yang berbunyi :

(2) proses seleksi pengangkatan hakim pengadilan negeri dilakukan bersama oleh mahkamah agung dan komisi yudisial

(3) ketentuan lebih lanjut mengenai proses seleksi diatur bersama oleh mahkamah agung dan komisi yudisial.

Pada tahun 2010, Mahkamah Agung telah melakukan seleksi hakim tanpa melibatkan Komisi Yudisial sehingga untuk menyelamatkan/melegalkan calon hakim yang terlanjur diterima melalui seleksi pengangkatan hakim yang diselenggarakan Mahkamah Agung dibuatlah Peraturan bersama Mahkamah Agung dan Komisi Yudisial Nomor 01/P/ 
MA/IX/2012-01/PB/P.KY/09/2012 tentang Seleksi Pengangkatan Hakim. pelaksanaannya tidak mudah untuk diterapkan oleh Mahkamah Agung dan Komisi Yudisial mengenai seleksi pengangkatan hakim. Tahun 2015, kewenangan Komisi Yudisial (KY) untuk ikut bersama menyeleksi hakim Pengadilan Negeri, Pengadilan Agama dan Pengadilan Tata Usaha negara dianggap inkonstitusional menurut putusan Mahkamah Konstitusi atas perkara nomor 43/PUU-XIII/2015. Menurut MK, KY yang lahir dalam perubahan UUD 1945, Pasal 24B ayat (1) UUD 1945, yang berbunyi: "Komisi Yudisial bersifat mandiri yang berwenang mengusulkan pengangkatan hakim agung dan mempunyai wewenang lain dalam rangka menjaga dan menegakkan kehormatan, keluhuran martabat, serta perilaku hakim.”

Mahkamah menegaskan, KY bukan merupakan pelaksana kekuasaan kehakiman, melainkan sebagai elemen pendukung atau state auxiliary organ, yang mendukung pelaku kekuasaan kehakiman. Selain itu, frasa "wewenang lain” dalam Pasal 24B ayat (1) UUD 1945 adalah semata dalam rangka menjaga dan menegakkan kehormatan, keluhuran, martabat, serta perilaku hakim, tidak dapat diperluas dengan tafsiran lain. UUD 1945 juga tidak memberi kewenangan kepada pembuat Undang-Undang untuk memperluas kewenangan KY.Mahkamah menyatakan, meskipun dalam Pasal 24 UUD 1945 tidak menyebutkan secara tersurat mengenai kewenangan Mahkamah Agung dalam proses seleksi dan pengangkatan calon hakim dari lingkungan Peradilan Umum, Peradilan Agama, dan Peradilan Tata Usaha Negara, akan tetapi ayat (2) dari Pasal 24 UUD 1945 telah secara tegas menyatakan ketiga Undang-Undang yang diajukan Pemohon dalam perkara ini berada dalam lingkungan kekuasaan kehakiman di bawah Mahkamah Agung. Mahkamah berpendapat seleksi dan pengangkatan calon hakim pengadilan tingkat pertama menjadi kewenangan Mahkamah Agung. MK memandang aturan yang memberikan kewenangan kepada KY untuk ikut bersama dalam proses seleksi hakim Pengadilan Negeri, Pengadilan Agama, dan Pengadilan Tata Usaha Negara adalah bertentangan dengan UUD 1945.

Mahkamah Agung dinyatakan sebagai lembaga yang berwenang dalam hal pengadaan dan rekrutmen hakim, namun permasalahannya MA malah kembali menggunakan sistem rekrutmen dengan sistem Calon Pegawai Negeri Sipil (CPNS) dalam proses rekrutmen calon hakim, hal itu dapat dilihat dengan dikeluarkannya Peraturan Mahkamah Agung (PERMA) Nomor 2 Tahun 2017 tentang Pengadaan Hakim, dan pada tahun itu juga telah dilaksanakan rekrutmen hakim tingkat pertama untuk Peradilan Umum, Peradilan Agama, Peradilan Tata Usaha Negara. PERMA tersebut mengatur kebutuhan formasi hakim ditentukan oleh 
pemerintah, yaitu Menteri Pendayagunaan Aparatur Negara dan Reformasi Birokrasi. Seleksi dan pengangkatan hakim juga dilakukan oleh pemerintah. Persis seperti system PNS, mereka yang lolos seleksi, akan diangkat terlebih dahulu menjadi Calon PNS (CPNS). Pasal 1 Angka 3 PERMA tersebut menyatakan:

"Calon Hakim adalah Calon Pegawai Negeri Sipil dan/atau Pegawai Negeri sebelum diangkat menjadi Hakim."

dalam Pasal 1 Angka 4 Peraturan Mahkamah Agung (PERMA) Nomor 2 Tahun 2017 menyatakan:

"Pengadaan Hakim adalah kegiatan untuk mengisi kebutuhan hakim yang berasal dari Pegawai Negeri Sipil."

Pasal 2 ayat (2 ) Peraturan Mahkamah Agung (PERMA) Nomor 2 Tahun 2017 menyatakan:

"Pengadaan Hakim sebagaimana dimaksud dalam ayat (1) dilaksanakan setelah mendapat penetapan kebutuhan Calon Pegawai Negeri Sipil oleh Menteri yang menyelenggarakan urusan pemerintahan dibidang pendayagunaan aparatur negara”.

Menurut Penulis, tidak salah kewenangan tunggal untuk melakukan rekrutmen hakim diberikan kepada Mahkamah Agung, karena Mahkamah Agung sendiri lah yang lebih mengetahui kebutuhan apa yang mereka butuhkan untuk mengisi jabatan hakim terutama di pengadilan tingkat pertama. Hal itu membuat MA menentukan semua proses baik seleksi, promosi hingga Pendidikan hakim tanpa melibatkan Lembaga lainnya, sistem rekrutmen ala CPNS yang dipakai MA dalam rekrutmen hakim tentu mencederai terkait kedudukan hakim sebagai pejabat negara dan menimbulkan penilaian apakah Mahkamah Agung kredibel dalam menghasilkan hakim yang berkualitas dan berintegritas? Apalagi hakim-hakim yang sebelumnya dihasilkan oleh Mahkamah Agung banyak yang bermasalah baik putusan yang dihasilkan maupun prilaku hakim yang melanggar kode etik. Keterlibatan Lembaga lain (misalnya Komisi Yudisial) dalam proses seleksi menurut penulis sangat penting sebab dengan itu akan ada shared responsibility yang bisa saling mengontrol agar bisa melahirkan hakim yang terbaik. Ditambah kewenangan Komisi Yudisial dalam menjamin kehormatan, keluhuran martabat, serta perilaku hakim yang baik harus dimulai dari awal, yaitu dimulai dari upaya menemukan calon hakim. 


\section{- Jepang}

Berdasarkan Pasal 81 Konstitusi Jepang, Mahkamah Agung (MA) Jepang adalah badan peradilan terakhir dengan kewenangan untuk memutuskan keabsahan hukum dari setiap hukum, aturan, regulasi, ataupun tindakan resmi. MA Jepang juga bertanggung jawab dalam mengangkat hakim pada peradilan di bawahnya, memutuskan prosedur yudisial, meninjau sistem yudisial Jepang, termasuk segala suatu aktivitas dari jaksa penuntut umum, dan menjatuhkan hukuman disiplin terhadap hakim dan perangkat hukum lainnya.

Hakim di pengadilan yang berada di bawah MA Jepang, mereka semua ditunjuk oleh Kabinet dan Kaisar dari daftar calon yang diajukan oleh Mahkamah Agung jepang. Rekrutmen hakim di semua tingkatan peradilan dilakukan oleh dan atas rekomendasi Chief of Justice (Ketua Mahkamah Agung) dan Sekretaris Jenderal Legal Training and Research Institute (LTRI(Parlina, 2018).Legal Training and Research Institute (LTRI) adalah lembaga dibentuk berdasarkan Pasal 14 UU Nomor 59 Tahun 1947 tentang Pengadilan. LTRI merupakan unit organisasi di bawah MA Jepang yang berfungsi sebagai pusat pelatihan hakim, pengacara, dan jaksa, serta pusat riset hukum di Jepang.Pencalonan hakim pengadilan yang lebih rendah membutuhkan saran dari Komite Penasihat untuk seleksi Hakim Pengadilan Bawah atau the Advisory Committee for the Nomination of Lower Court Judges(Parlina, 2018).Sekretariat Jenderal Mahkamah Agung yang telah melakukan penyaringan dan telah menyiapkan daftar asisten hakim dan hakim untuk pencalonan, dan Konferensi Yudisial hanya mengkonfirmasi daftar-daftar itu. Untuk memperkuat kepercayaan rakyat terhadap seleksi hakim, dibentuk lembaga khusus dalam Mahkamah Agung yang lebih berwenang dominan dalam proses seleksi . mekanisme ditetapkan untuk memastikan bahwa prosesnya transparan, termasuk mengungkapkan standar seleksi, prosedur, jadwal dan hal-hal lain (Rasmusen, 2013).

Pada tahun 2003, Mahkamah Agung membentuk Komisi Konsultasi Penunjukan Hakim Pengadilan Rendah (Kakyūsaibansho saibankan shimei shimon iinkai). sebelas anggota yang berada di dalamnya Mahkamah Agung. Anggotanya ditunjuk oleh Mahkamah Agung, tetapi sebagian besar berasal dari luar peradilan. Komisi itu terdiri dari dua hakim, dua pengacara, satu jaksa, dan enam orang akademisi, serta dari luar profesi hukum yang professional dan berpengalaman. Komisi konsultasi seleksi hakim ditugasi untuk mengkaji dan mengevaluasi kandidat yang ditunjuk sebagai asisten hakim atau hakim yang kembali mengajukan diri sebagai hakim, berdasarkan daftar kandidat yang disiapkan oleh Sekretariat Jenderal 
Mahkamah Agung, dan lalu melaporkan penilaian itu kepada Mahkamah Agung. Komisi dibantu oleh bagian urusan umum, dengan staf oleh anggota Sekretariat Jenderal Mahkamah Agung. Delapan badan regional juga dibentuk, satu di masing-masing dari delapan badan tinggi yurisdiksi pengadilanuntuk membantu komisi dalam mengumpulkan informasi mengenai para kandidat (Rasmusen, 2013). Mahkamah Agung tidak terikat secara hukum untuk mengikuti pandangan Komisi dalam mempersiapkan daftar calon yang ditunjuk untuk diserahkan kepada Kabinet.Sekretariat Jenderal mempersiapkan hal untuk mengajukan kandidat hakim, dan subkomite beranggotakan lima orang Komisi kemudian meninjau kandidat dan melaporkan kembali secara penuh pertimbangan Komisi. Untuk pengangkatan dan seleksi asisten hakim baru, nilai di LTRI merupakan faktor utama, ditambah dengan laporan penilaian yang disiapkan oleh hakim sebagai instruktur di LTRI.

Menurut penulis, berdasarkan uraian terkait Lembaga yang melakukan seleksi di Jepang bisa dinilai kredibel sebab dalam proses rekrutmen itu Mahkamah Agung bukan Lembaga yang mendominasi semua proses seleksi, karena ada Lembaga lain yang diberikan kewenangan untuk ikut dalam proses tersebut. LTRI (Legal Training and Research Institute) mempunyai peran yang cukup penting sebab Lembaga ini lah yang bertanggung jawab untuk melakukan pelatihan kepada calon hakim dan mungkin yang paling mengetahui kemampuan dari calon hakim baik dari segi kemampuan hukumnya (teori dan praktek) maupun segi moralnya. Apalagi sudah ada Komite Penasihat untuk seleksi Hakim Pengadilan Bawah atau the Advisory Committee for the Nomination of Lower Court Judges yang bisa memberikan saran dan pertimbangan kepada Mahkamah Agung bahwa hakim yang sudah dilatih ini memiliki kualitas dan berintegritas dan layak untuk dilantik. Pembagian peran antara Mahkamah Agung, LTRI, dan Komite penasihat seleksi hakim ini, penulis menilai Lembaga yang berwenang melakukan seleksi hakim itu telah kredibel dalam melaksanakan tugas dan tanggung jawabnya.

\section{Metode ujian dalam tes calon hakim}

\section{- Indonesia}

Bentuk soal yang dipergunakan dalam ujian adalah pilihan ganda (multiple choice) berbasisComputer Assisted Test (CAT). Test pertama yaitu Seleksi Kompetensi Dasar (SKD) yang terdiri atas a) Tes Karateristik Pribadi; B) Tes Intelegensia Umum; dan c) Tes Wawasan Kebangsaan. Model soal dengan format pilihan ganda atau sejenis itu dipilih Mahkamah Agung karena proses pemeriksaannya lebih mudah, cepat dan hasilnya bisa langsung 
diketahui seketika tes selesai. Namun pertanyaan dengan model pilihan ganda kembali dipakai dalam tahap selanjutnya yaitu Tes Kemampuan Bidang Hukum, tes tersebut dinilai kurang dapat menggali kemampuan pengetahuan hukum calon secara mendalam. karena bisa saja skor yang didapat itu hasil keberuntungan belaka, berbeda jika menggunakan metode pertanyaaan essay yang bisa saja akan menggali semua pengetahuan hukum calon hakim terutama dalam analisis teori dan hukum acara.Tahap selanjutnya yaitu wawancara dan psikotes, dimana pada seleksi Calon Hakim tahun 2017 peserta diwawancarai oleh penginterview dari internal Mahkamah Agung yang kebanyakan hakim senior serta akademisi dari Universitas Terkemuka. Selain test kepribdian, setiap peserta seleksi akan diwawancarai mengenai hal-hal seputar motivasi, pengetahuan umum dan pengetahuan hukum. Ujian psikotes atau uji kepribadian dengan bekerja sama dengan lembaga psikologi yang ditunjuk, namun sayangnya soal-soal yang diajukan dalam psikotes belum diarahkan secara spesifik pada pelaksanaan fungsi hakim. wawancara penulis dengan Ridwan Syarif mengatakan ketika proses wawancara tidak menggali secara mendalam pengetahuan si calon mengenai pengetahuan di bidang hukumnya terutama hukum acara (Syarif, 2019).

Pembenahan perekrutan hakim tidak cukup hanya dilakukan dengan mengadopsi sistem terkomputerisasi atau computer assisted test (CAT). Mengadopsi sistem tersebut sebagaimana seleksi calon aparatur sipil negara (ASN) tentu akan menambah nilai transparansi dan akuntabilitas. Namun, penting juga untuk dipahami bahwa sistem tersebut tidak serta-merta memberikan jaminan perekrutan dilakukan tanpa celah kecurangan. MA harus pula mengidentifikasi potensi kecurangan yang mungkin tetap dapat terjadi dalam perekrutan hakim dengan sistem terkomputerisasi. Computer Assisted Test (CAT) dalam beberapa tahapan seleksi ditambah waktu yang singkat apakah cukup untuk bisa menghasilkan calon hakim yang berkualitas dan berintegritas?

Potensi kecurangan masih dapat terjadi mengingat sistem komputerisasi tidak seratus persen meng-cover perekrutan hakim. Beberapa tahapan yang dilakukan secara manual oleh panitia seleksi. Seleksi administrasi misalnya, pengecekan kelengkapan berkas calon masih dilakukan secara manual memungkinkan terjadinya praktik nepotisme di mana seleksi didasarkan pada kedekatan calon dengan hakim dan/atau pegawai MA. Tahapan ini juga rentan terhadap intervensi dari hakim dengan cara menitipkan calon yang memiliki hubungan kekerabatan agar diluluskan dalam seleksi administrasi (IDRIS, 2017). 
- Jepang

Setiap peserta calon hakim yang telah lulus Law School (setingkat magister hukum) harus mengikuti ujian negara yang seleksinya sangat ketat antara lain tes bakat kemampuan dasar dan materi hukum terutama hukum acara. Bentuk ujiannya adalah soal pilihan ganda, essay dan wawancara. Tidak ada perbedaan materi ujian pada tahap ini untuk calon hakim, penyidik, penuntut maupun pengacara. Pemeriksaan kedua terdiri dari tes tertulis (tanya jawab dan esai) dan tes lisan. Tanya Jawab ada pada tiga subjek Konstitusi Jepang, KUHPerdata dan KUHP, sedangkan esai dan ujian lisan ada pada enam subjek Konstitusi Jepang, KUHPerdata, KUHP, Hukum Dagang, subjek opsional tentang hukum acara dan subjek opsional pada materi bidang hukum lain dan soal esai akan diuji mengenai enam mata pelajaran Konstitusi Jepang, Hukum Perdata, Hukum Pidana, Hukum Dagang, Hukum Acara Perdata, dan Hukum Pidana Prosedur, sedangkan tes lisan akan pada lima mata pelajaran tidak termasuk Hukum Dagang) (Rasmusen, 2013).

Seleksi mempunyai peran yang amat menentukanuntuk menjaring calon hakim yang mempunyai kualifikasi di atas dan mumpuni,. Seleksi yang mempergunakan metode tertentu dan dilaksanakan secara objektif akan dapat menjaring calon hakim yang sekurang-kurangnya mendekati ideal yaitu berwibawa, jujur, adil dan berkelakuan tidak tercela, seleksi calon hakim yang bersifat subjektifharus dihindari (Bambang Sutitoso, 2005). Hakim adalah subjek yang paling wajib menguasai segala bidang hukum baik teori ataupun prakteknya dibanding siapapun di ruang sidang. orang-orang yang mendaftar menjadi hakim seharusnya adalah orang-orang yang sedari awal merupakan bibit-bibit yang bagus, yang memang terniat menjadi hakim, bukan orang yang sekedar ikut dan berharap rejekinya menjadi seorang hakim. Proses seleksi hakim seharusnya harus dibuat sesulit-sulitnya sehingga mampu menggali secara mendalam pengetahuan calon hakim itu dalam bidang hukum. Hakim itu harus pintar dalam ilmu hukum ataupun teknis hukum (Isra, 2014). Hakim kualitasnya harusnya diatas ilmu jaksa dan pengacara karena posisinya sebagai penilai dan pemutus suatu perkara. Jika kualitas hakimnya lebih rendah, maka hakim akan mudah dipengaruhi dalam persidangan. Proses rekrutmen sangat penting karena menyangkut hakim yang akan dihasilkan nantinya. seorang Hakim idealnya harus mampu melihat proses penegakan hukum tersebut dari berbagai aspek dan sudut pandang. Kemampuan dan keahlian ini tentunya tidak diperoleh secara instan tapi harus melalui suatu proses belajar panjang (Amos, 2007). 
Bagaimanapun mekanisme perekrutan seorang untuk menjadi hakim akan menentukan kualitas putusan pengadilan ke depannya. Seseorang yang sejak awal memang memiliki kapabilitas dan wawasan hukum yang mendalam sudah selayaknya terjaring dalam rekrutmen hakim sehingga mereka yang nantinya duduk di muka ruang pengadilan sebagai pemimpin sidang adalah hakim-hakim yang berkualitas terbaik. Putusan pengadilan yang kontroversial terus bermunculan sehingga berbagai pihak menilai hakim-hakim di negeri ini belum memahami rasa keadilan masyarakat. Banyaknya kelemahan ataupun cacat hukum pada putusan yang dikeluarkan oleh para hakim bisa jadi merupakan gambaran dari tidak efektifnya pola rekrutmen hakim yang selama ini diterapkan di Indonesia.(Djohansjah, 2008)

Rekrutmen hakim Indonesia terutama untuk Pengadilan Tingkat Pertama hanya untuk mengisi lowongan yang kosong dan kekurangan hakim terutama di pengadilan di daerah. Jika dalam hasil rekrutmen, ada calon yang seharusnya tidak memenuhi standar nilai yang diinginkan panitia seleksi (Mahkamah Agung), namun dalam sisi lain adanya kebutuhan mendesak untuk mengisi formasi hakim yang kosong, maka MA tetap akan merekrut calon tersebut demi kuota yang telah ditentukan bersama kementerian aparatur negara dan reformasi birokrasi. Akhirnya yang dijadikan ukuran utama bukan lagi kualifikasi calon, tetapi ada tidaknya personalia yang dapat mengisi formasi yang kosong, secara tidak langsung membawa beberapa implikasi negatif, antara lain menurunkan posisi tawar pengadilan terhadap negara, merugikan prestise jabatan hakim, dengan menurunnya prestise menjadi hakim, semakin sulit pengadilan untuk pengadilan mendapatkan lulusan fakultas hukum yang bermutu untuk menjadi hakim jika yang diutamakan adalah kuota formasi hakim itu terpenuhi (Agung, 2003).1

\section{KESIMPULAN}

Berdasarkan uraian singkat diatas, maka dapat dibedakan metode rekrutmen hakim antara di Indonesia dengan Jepang. Mekanisme pengisian jabatan hakim di Indonesia menggunakan sistem rekrutmen CPNS, dan Mahkamah Agung sebagai lembaga satu-satunya yang berwenang penuh dalam semua tahapan dari rekrutmen, Pendidikan sampai pengangkatan sebagai hakim. Sedangkan mekanisme pengisian jabatan hakim di jepang Untuk hakim di pengadilan yang berada di bawah MA Jepang, calon hakim semua ditunjuk oleh Kabinet dan Kaisar dari daftar calon yang diajukan oleh Mahkamah Agung Jepang.

${ }^{1}$ Mahkamah Agung,Kertas Kerja Pembaruan Sistem Pembinaan SDM Hakim, Jakarta, 2002, hlm 93 
Menurut peraturan yang berlaku, pencalonan hakim pengadilan yang lebih rendah membutuhkan saran dari Komite Penasihat untuk Nominasi Hakim Pengadilan Bawah atau the Advisory Committee for the Nomination of Lower-Court Judges. Selain itu ada Legal Training and Research Institute yang berwenang melakukan pelatihan terhadap calon hakim. Dari sisi apakah Lembaga yang berwenang melakukan seleksi hakim di Indonesia dan jepang itu penulis menganggap keduanya sudah kredibel tetapi jepang lebih baik sebab pengisian jabatan hakim mereka melibatkan banyak Lembaga lain dan saling shared responsibility untuk bisa menghasilkan hakim yang berkualitas dan berintegritas. Berbeda dengan Indonesia karena semua tahapan mutlak kewenangan ada pada Mahkamah Agung. Lalu dari segi sejauh mana mekanisme pengisian jabatan hakim di Indonesia dan Jepang mampu untuk menghasilkan hakim yang berkualitas dan berintegritas menurut penulis kedua negara sudah berupaya yang terbaik untuk menghasilkan hakim yang berkualitas dan berintegritas, tapi penulis menilai mekanisme pengisian jabatan hakim di jepang kembali lebih baik sebab prosesnya dilakukan secara terbuka, selektif, dan kompetitif, banyak tahapan yang harus dilalui calon hakim itu bisa diangkat menjadi hakim baik persyaratan, strata pendidikan, pengalaman dibidang hukum, metode ujian. Ditambah Jepang telah memiliki model kompetensi standar yang dijadikan acuan dalam proses rekrutmen maupun pelatihan bagi calon hakim selain itu, dalam model acuan itu terdapat karakter ideal yang sepatutnya dipunyai oleh setiap hakim sehingga lahir hakim yang mempunyai kualitas dan mutu yang sama bagusnya. Indonesia sendiri menurut penulis dari segi mekanisme pengisian hakim belum sepenuhnya mampu secara maksimal menghasilkan hakim yang berkualitas dan berintegritas.

\section{KEPUSTAKAAN}

Alia, M. I. (2017, Mei 27). Mengurai Polemik Rekrutmen Hakim. Diambil kembali dari Geotimes: https://geotimes.co.id/kolom/hukum/mengurai-polemik-rekrutmen-hakim/

Badilag Mahkamah Agung. (2017, Maret 31). Seleksi dan Gaji Hakim Jepang Terungkap di PA Depok. Diambil kembali dari Direktorat Jenderal Badan Peradilan Agama Mahkamah Agung: https://badilag.mahkamahagung.go.id/seputar-ditjenbadilag/seputar-ditjen-badilag/seleksi-dan-gaji-hakim-jepang-terungkap-di-pa-depok

Council, T. S. (1999, juli). The Japanese Judicial System. Diambil kembali dari Japan Kantei: https://japan.kantei.go.jp/judiciary/0620system.html 
Marzuki, S. (2018). Menimbang Hakim Sebagai Pejabat Negara. Dalam K. Yudisial, Meluruskan Arah Manajemen Kekuasaan Kehakiman (hal. 22). Jakarta: Sekretariat Jenderal Komisi Yudisial.

pengujian terhadap Undang-Undang Nomor 49 Tahun 2009 tentang Peradilan Umum, Undang-Undang Nomor 50 Tahun 2009 tentang Pengadilan Agama, dan UndangUndang Nomor 51 Tahun 2009 tentang Pengadilan Tata Usaha Negara, Putusan Mahkamah Konstitusi 43/PUU-XIII/2015 (Mahkamah Konstitusi 2015).

Rimdan. (2012). Kekuasaan Kehakiman Pasca-Amandemen Konstitusi. Jakarta: Kencana.

Syahuri, T. (2013). Sistem Rekrutmen Hakim Berdasarkan Tiga Undang-Undang Bidang Peradilan Tahun 2009 Untuk Mewujudkan Peradilan Bersih. Jurnal Yudisial, 14.

Yudisial, K. (2015). The Research and Training Institute of Ministry of Justice dan Legal Training and Research Institute, Supreme Court of Japan . Jakarta: Komisi Yudisial. 